\title{
Social Trust and Internal Control Quality - Evidence from China
}

\author{
$\mathrm{Han} \mathrm{Li}^{1}$ \\ ${ }^{1}$ SILC Business School, Shanghai University, Shanghai, China \\ Correspondence: Han Li, SILC Business School, Shanghai University, 20 Chengzhong Road, JiaDing District, \\ Shanghai 201800, China. Tel: 86-21-6998-0028 ext.53101.
}

Received: February 6, 2017

Accepted:March 5, 2017

Online Published: March 14, 2017

doi:10.5430/ijfr.v 8n2p92

URL: https://doi.org/10.5430/ijfr.v8n 2p92

\begin{abstract}
This paper investigates the relationship between social trust and internal control quality. It is found that in general, social trust has strongly associated with internal control quality. When the variable $N G O$ substitutes for social trust, the similar result is arisen. Furthermore, when the variable $I C Q$ is more than third quartile in the $I C Q$ index, social trust has positively relationship with the $I C Q$; on the contrary, when the variable $I C Q$ is less than one quartile in the $I C Q$ index, social trust has negatively relationship with the $I C Q$. This paper also testifies the trust residual that sites out the managerial ability factor from trust index is also positively related with the variable $I C Q$ at the confidence level of $1 \%$. In sum, trust is as sociated with internal control quality based on the evidence from China.
\end{abstract}

Keywords: social trust, internal control quality, financial reporting quality, corporate governance, Chinese listed firm

\section{Introduction}

In the financial research, how to solve for agency problems in corporate governance and to protect the shareholders' interests is always the hot debate. Therefore, to set up an effective internal control framework and to increase the internal control quality has always been considered for firms' business administration. Similar as the implementation of a complete internal control framework for listed firms that advocated by the Sarbanes-Oxley Section (SOX) in 2002 in USA, all listed firms in China are required to disclose their internal control reports in 2012. To imp rove the quality of internal control is the compulsory assignment and duty for all the firms. Many researches find that higher internal control quality will decrease the cost of finance, increase the earning quality, increase the reputation for the firms, reduce the financial risks, imp rove the accuracy of the guideline and decrease the probability of insider trading, etc. On the other hand, many researches involve in investigating the drivers of internal control quality. These drivers could be firm size, financial leverage, business complexity, corporate governance, financial risk, managerial ability, etc. However, some potential variables that would also matter for the improvement of internal control quality are still not very clear for the researchers. Trust including social trust could be one of these undiscovered variables. The effect of trust normally is discussed in psychological perspective. Few researches are about the contribution of trust from the financial and economic perspectives. In the current academic literature of trust, social trust has much focused on the earning management, cost of financing and corporate governance. But we still do not know whether social trust matters for internal control quality. This paper tries to fill in this gap.

In this research, the majority data is from CSMAR database and DIB database. After the deletion of some specific firms, such as financial institutes, ST shares and B shares and the firms with missing data, 543 sample firms are finally selected. Based on the regression analysis, the results show that in general social trust is positively associated with internal control quality. This relationship is statistically significant in the confidence level of $1 \%$. Prior research shows that the development of non-government organization (abbreviated as $N G O$ thereafter) reflects the trust level. In other words, higher NGO develop ment index means higher level of trust. When the variable $N G O$ that reflects the development of non-government organization substitutes for the variable Trust, the variable $N G O$ has positive association with the variable ICQ. Moreover, this paper tries to find the features of the relations hip between Trust and $I C Q$ when the $I C Q$ is extreme high or extreme low. It shows that when the firms whose $I C Q$ are larger than third quartile in the whole ICQ index, Trust is positively associated with $I C Q$ at statistical significant level. On the contrary, when the firms whose $I C Q$ are less than one quartile in the whole ICQ index, Trust is negatively associated with $I C Q$. This means that when the internal control quality is very low, abnormal trust within the firm that would reduce the compliance monitoring will inversely influence the internal control quality and reduce the internal control quality. 
There may be other factors that influence trust and internal control quality. Top executive's ability could be one of these potential factors. In other words, higher managerial ability leads to higher trust, then higher internal control quality. Therefore, in the robust test section, this paper sites out the factor - Managerial Ability from the variable Trust and then the variable Trust_Residual is got. The Trust_Residual reflects the specific trust level which is not due to managerial ability. The analysis of regression Trust_Residual and ICQ shows that Trust_Residual and ICQ has positively related at the statistically significant level.

This paper is arranged as follows: Part I, Introduction section; Part II, Literature review and hypothes is development; followed with Part III, Sample Selection and variable definition; Part IV, Research design and results; Part V, Robust Test; finally, conclusions and references.

\section{Literature Review and Hypothesis Development}

\subsection{Prior Research on Internal Control Quality}

Internal control quality is to measure the effectiveness of the firm's internal control framework over financial and managerial activities. The internal control framework includes the environment, risk evaluation, supervision activities, overseas and information and communication. The Sarbanes -Oxley Section (SOX) which enacted in 2002 in USA is designed to protect the investors' interests through setting up with higher standard corporate governance and internal control regulations. The section 404 of SOX requires the firms to evaluate the effectiveness of internal controls through disclosing the internal control reports periodically. Many researches testify that higher internal control quality will lead to higher financial reporting quality. Kim et al. (2011) advocates that internal control weakness which leads to lower internal control quality will increase the cost of financing in bank loans. Higher cost of debt would decrease the value of the firm. Goh and Li (2011) find that disclosing internal control weakness (ICWs) for the firms leads to lower conditional conservatism compared with those without disclosing ICWs. Fend et at. (2009) asserts that ineffective internal control will result in less accurate guidance. Furthermore, the firms with internal control weakness will also be found the evidence that the probability of insider trading is higher (Skaife, et al.2013). Internal control related framework issued by COSO (Committee of Sponsoring Organizations of the Treadway Commission) has the effects of higher loan-loss provision validity, more earnings persistence, higher cash flow predictability and lower benchmark beating activities (Altamuro, Beatty, 2010). In sum, higher internal control quality leads to higher values of the firms.

Internal control quality reflects the contents of the firms' satisfaction to the disclosure control and procedure that required by the regulation, such as SOX section 404 and section 302 in USA. The scholars build up the literature of the causes of the internal control deficiencies (abbreviated as ICDs thereafter) and investigate numerous factors that influencing the internal control quality (abbreviated as ICQ thereafter). Doyle et al. (2006) thin k that ICDs in a firm are more related with the size, financial conditions, business complexity, growth and restricting. Smaller size, weaker financial performance, more complicated business activities, faster growth and restructuring would cause higher ICDs. Similarly, it is also found that firms that report ICDs have more complex business activities that arisen from business segments and foreign transactions, more engagements in mergers and acquisitions, more inventory holdings and more times of auditor resignations and higher incidences of restatements (Ashbaugh-Skaife, H., et al, 2007). The internal control quality can also be improved by strengthening the corporate governance (Hoitash, et al.,2009). Naiker and Sharma (2009) indicate that the audit committee features are correlated with more effective of internal controls quality over financial reporting.

In the literature of internal control research, many research results focus on the consequences of ICQ as well as the factors of influencing on the quality of internal control. This paper will further investigate that the trust should not be ignored to improve the internal control quality.

\subsection{Research on Social Trust}

Adam Smith had discussed that economic activities are based on social habits and moral sentiments. Less or even without trust will lead to severe immoral behavior. Distrust behavior would damage the basis of business transaction within the society. There are many diversified defin itions about trust. Sabel (1993) defined trust as follows "trust is the mutual confidence that no party to an exchange will explo it another's vulnerabilities". That means moral hazard, adverse selections and other vulnerabilities would be avoided partly under the trust by which all parties share a common confidence. Rousseau et al. (1998) conceptualized trust as follows "a psychological state comprising the intention to accept vulnerability based upon positive expectations of the intentions or behavior of another". Fukuyama (2005) advocates that one of the determinants of trust is the norm of culture. He believes that the community relies on trust and in return, trust would also be influenced. 
Unlike the sociological analysis that trust has close relationship with culture virtual, trust is actually the results of peoples' rational choices from the economic po ints of view. To strive for long term interests will lead to trust among people (Kreps, 1986; Fudenberge \& Tirol, 1992; Zhang, 2002). Luhmann (1979) and Zucker (1986) indicate that "trust is a business risk that relied on confidence in the predictability of one's expectation". The stakeholders will cover their risks by more formal committed contracts to avoid the moral hazard and adverse selection problems; While, Dore (1983) thinks that the confidence on trust is based on another's goodwill and reputation. Mutual values and interpersonal reputation and moral behaviors matter for the trust (Ring and Van De Ven, 1994). In the development literature on trust, many scholars advocate that trust is the vital factor in alliance governance structure, foreign subsidiary commitment (Gulati, 1995; Kim and Mauborgne, 1993). Higher level trust will lead to better communication, more effective in managerial problem solving (Boss, 1978), more transformational leadership and more satisfaction with supervis or (Dirks and Ferrin,2002), better organizational citizenship behavior (Robinson,1996). Trust also will indirectly influence performance (Porter, 1996). It has the positive effects on job satisfaction, commitment and compliance with decision (Rich, 1997; Brockner et al., 1997; Kim and Mauborgne, 1993).

China, as the largest developing country, is quite different in economic and political and cultural backg rounds compared with other developed and western countries. The developments of economies in China are driven by the market and the government at the same time. In the long history of China, trust among people varies with the region and times. Trust normally arises from the family members and close relationship people for Chinese. Although trust among peoples sometimes can exceed over the ties of blood, region and family, the extended scope of trust in China has its boundaries that are influenced by the mainstream ideas in the times. On the contrary, trust in western countries can arise from the law, social contractual agreement and marketable transaction rather than the ties of relatives and regions (Chu \& Li, 2003).

The research of trust is not only in sociology but also in economics and management. It is found that higher trustworthiness will lead to higher trust and higher social capital (LLSV 1997, Fukuyama 1995). Many research es investigate the relationship between social capital (or social trust) and other financial and accounting factors (Note 1). Social trust and political ties have significant influences on the bank loan of the private firm in China (Zhang and Li, 2012). Pan et al. (2010) deeply explores the mutual substitutions role of social capital and law protection in earning management decision. Social capital contributes to the innovation development and economic growth (Yan, 2012). The perception of management (including the perception of trustworthiness) is associated with financial reporting quality (Garrett et al., 2014). In sum, trustworthiness is a source of competitive advantage in business (Barney and Hansen, 1994). In this research, due to the availability of data, social trust that measures the trust level for a society substitutes for trust as the testable variable in whole analysis.

\subsection{Hypothese Development}

The purposes of policy and regulation are to guarantee the stakeholders behavior as expected. The internal control framework as a series of regulations in business is a systematic arrangement to balance the interests and responsibilities of each stakeholder within the organizations. To imp rove the internal control quality, the firms should build up the formal internal control framework which is designed and required by internal control framework, such as COSO (Note 2) in USA. COSO's key definition about the internal control is as follows, "Internal control is a process effected by an entity's board of directors, management, and other personnel, designed to provide reasonable assurance regarding the achievement of objectives relating to operations, reporting, and compliance." The framework consists of 5 integrated components of internal control: control environment, risk assessment, control activities, information \&communication and monitoring activities. In the COSO 2013 framework, clear and open communication, responsibility and ethical values are required for the effective internal control. Within the dimension of control environment, "Demonstrates commitment to integrity and ethical values." And "Exercises oversight responsibility"; Within the dimension of information \& communication, "Uses relevant information", "Communicates internally" and "Communicates externally" (COSO 2013). All these factors are related to trustworthiness. Trust is the fundamental ethical value and higher trust level will significantly make the communication more effective and efficient. Therefore, trust is the bas is for the ethical value and communication which are the drivers for influencing the internal control quality.

The methods to accomplish for the control purposes can be formal or in formal. However, under many conditions, the formal system does not play effective roles as expected. Due to the limitation of decision makers' knowledges experiences and uncertainty for the future, the internal control system cannot be perfect. Ouchi (1979) believes that culture is a powerful informal control factor. Informal rules, i.e. culture, religion, may make up the imperfect features 
for the formal and contractual internal control system. Sometimes, formal controls and informal controls are inversely related (Das and Teng, 1998). Trust as an information rule and internal control regulation as a formal rule are the mutual substitutes and the complement factors. The informal rules are mainly based on reputation and trust. Therefore, trust is not only the basis of the design of internal control framework, but also the safeguard of execution of internal control system (Xu and Lin, 2011). Based on the prior researches (Doyle et al., 2006; Ashbaugh-Skaife, H., et al, 2007; Hoitash, et al.,2009; Naiker and Sharma, 2009), the regression model is made as follows:

Hypothesis 1: Trust is positively related with internal control quality in China.

$$
\begin{aligned}
& \text { ICQ }_{\text {it }}=\alpha_{0}+\alpha_{1} \text { Trust }_{i t}+\alpha_{2} \text { LnAssets }_{i t}++\alpha_{3} \text { LnAge }_{i t}+\alpha_{4} \text { LnShare }_{i t}+\alpha_{5} \text { BusiComplexity }_{i t}+\alpha_{6} \text { Merge }+\alpha_{7} \text { ForeignTrans }_{i t} \\
& \quad+\alpha_{8} \text { Loss }_{i t}+\alpha_{9} \text { Sales Growth }_{\text {it }}+\alpha_{10} \text { Big }_{i t}+\alpha_{11} \text { AuditReport }+\alpha_{12} \text { LnBoD }_{\text {it }}+\alpha_{13} \text { State }+\alpha_{14} \text { Sales STD }_{\text {it }}+\alpha_{15} \text { Year }_{i t}+\varepsilon
\end{aligned}
$$

(Model 1)

Where does higher quality of trust come from? Researchers find that family, blood-ties relationship, the developments of NGOs and culture matter for trust. Trust would be raised and increased as the results of gaming for the transactions among people. Any factors that contribute to the repetitive transaction gaming would be the basis for the formation of trust, such as, property rights, NGOs, transaction facilities, geographic distances, enterprises' features and even top executives' abilities (Zhang, 2002). In China, firms located in different provinces will face with different development of market economies, property protections, transaction facilities and cultures. Fukuyama (1995) discussed that social organizations are the functions of societies trustworthiness. The developments of social organizations are based on whether the society belongs to high trust level society or low trust level society. Higher trust level society would cause higher matured social organizations and larger numbers of social orga nizations. The developments of non-government organizations determine the society trust level. Then, the indicators of $N G O s$ reflect the trust level.

Hypothesis 2: The developments of NGOs which reflect the trust level is positively associated with internal control quality in China.

$$
\begin{aligned}
& \mathrm{ICQ}_{\mathrm{it}}=\alpha_{0}+\alpha_{1} \mathrm{NGO}_{\mathrm{it}}+\alpha_{2} \text { LnAssets }_{\mathrm{it}}++\alpha_{3} \text { LnAge }_{\text {it }}+\alpha_{4} \text { LnShare }_{i t}+\alpha_{5} \text { BusiComplexity }_{\mathrm{it}}+\alpha_{6} \text { Merge }+\alpha_{7} \text { ForeignTrans }_{\text {it }}
\end{aligned}
$$

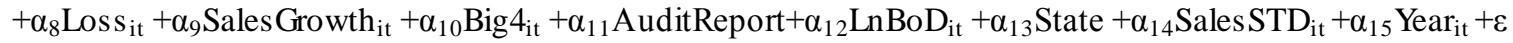

(Model 2)

In extreme high level of internal control quality firms, higher trust level would play a positive influence on internal control quality. However, in extreme low level of internal control quality firms, abnormal trustworthiness would cause less effective communication, less control on the compliance of financial reporting, lower property protection and therefore, lower internal control quality in the end.

Hypothesis 3: In higher ICQ level firms, trust is positively associated with internal control quality; On the contrary, in lower ICQ level firms, trust is negatively as sociated with internal control quality.

ICQ_high ${ }_{\text {it }}=\alpha_{0}+\alpha_{1}$ Trust $_{\text {it }}+\alpha_{2}$ LnAssets $_{i t}++\alpha_{3}$ LnAge $_{i t}+\alpha_{4}$ LnShare $_{i t}+\alpha_{5}$ BusiComplexity $_{i t}+\alpha_{6}$ Merge $+\alpha_{7}$ ForeignTrans $_{\text {it }}$ $+\alpha_{8}$ Loss $_{i t}+\alpha_{9}$ Sales Growth $_{\text {it }}+\alpha_{10}$ Big $_{i t}+\alpha_{11}$ AuditReport $+\alpha_{12}$ LnBoD $_{i t}+\alpha_{13}$ State $+\alpha_{14}$ Sales STD $_{i t}+\alpha_{15}$ Year $_{i t}+\varepsilon$

(Model 3)

ICQ_low it $_{1}=\alpha_{0}+\alpha_{1}$ Trust $_{\text {it }}+\alpha_{2}$ LnAssets $_{\text {it }}++\alpha_{3}$ LnAge $_{\text {it }}+\alpha_{4}$ LnShare $_{i t}+\alpha_{5}$ BusiComplexity $_{\text {it }}+\alpha_{6}$ Merge $+\alpha_{7}$ ForeignTrans $_{\text {it }}$ $+\alpha_{8}$ Los $_{i t}+\alpha_{9}$ Sales Growth $_{\text {it }}+\alpha_{10}$ Big $_{i t}+\alpha_{11}$ AuditReport $+\alpha_{12}$ LnBoD $_{i t}+\alpha_{13}$ State $+\alpha_{14}$ Sales STD $_{i t}+\alpha_{15}$ Year $_{i t}+\varepsilon$

(Model 4)

\section{Sample and Measurement about the Main Variable}

\subsection{Sample Selection}

This research collects the data of listed firms in Chinese stock markets - Shanghai Stock Exchange and Shenzhen Stock Exchange from 2009 to 2012. The financial reporting information derives from CSMAR database. Meanwhile, the data of internal control quality is based on DIB internal control index which is developed by DIB Enterprise Risk Management Technology Co., Ltd. To make unbiased statis tical results, this research ignores some specific firms by considering some firms' special features in Chinese markets, such as, commercial banks, insurance firms, security firms, B-Share firm, ST firms (Note 3). Finally, those firms missing data is also deleted from the analysis. In sum, there are total 543 sample firms with 2172 groups of data. 


\subsection{Dependent Variable}

\section{Internal Control Quality (ICQ)}

DIB internal control inde $x$ is to measure Internal Control Quality. DIB internal control index is the weighted average index based on the assessment of five integrated components of internal control: control environment, risk assessment, control activities, information \&communication and Monitoring activities. The index is published annually.

\section{High Internal Control Quality (ICQ_high)}

To measure the higher level of internal control quality, any ICQ index that is more than $75 \%$ percentile of index is selected. The variable ICQ_high is a dummy variable. If the ICQ index is more than 75\%, it is the high level ICQ quality. Then, the variable $I C Q \_h i g h$ is equal to 1 , otherwise, it is 0 .

\section{Low Internal Control Quality (ICQ_low)}

To measure the lower level of internal control quality, any ICQ index that is less than $25 \%$ percentile of index is selected. ICQ_low is a dummy variable. If the ICQ index is less than $25 \%$, it is the low level ICQ quality. Then, the variable ICQ_low is equal to 1 , otherwise, it is 0 .

\subsection{Testible Variable}

\section{Social Trust (Trust)}

Trust is measured based on the trust index of each province in China according to the research of a cross -regional trust analysis by Zhang and Ke (2002). This trust index is the results of the survey from 5,000 enterprises. This survey investigated the enterprises across 31 provinces in China. The $1^{\text {st }}$ rank trust index based on the survey is used in this research.

\section{NGOs (NGO)}

The development of NGOs can reflect the trust level of each region. Therefore, the NGOs index based on the research of business environment index for China's provinces by Wang (2013) is used.

\subsection{Control Variable}

Variables related to firm characteristics, firm business complexity, financial risk, corporate governance and year are controled. The detail definition about the control variable is in the table of appendix.

\section{Research Design and Results}

\subsection{Descriptive Data and Correlation Analysis}

\subsubsection{Descriptive Analysis}

In the table 1 , there are 543 sample firms with 2,172 observes are selected for analysis. ICQ's mean is 672.2 with the range from 0 to 981.8 . It reflects that the internal control quality for these listed firms is good in general. The variable ICQ_high and ICQ_low are du mmy variables. The minimu m and maximu m is from 0 to 1 for both variables. $N G O$ is the index for the development of NGOs. The average is 3.096 and the range is from 2.690 to 3.330 . It shows that the development of NGOs is very well. Trust on average is 5.927 with the maximum 22.70. This result seems that trust level in average is not very high.

For the following control variables, LnAssets, LnAge and LnShare show that majority selected firms hold large amounts of assets, longer age and higher percentage of equity held by major shareholders. BusiComplexity, Merge and ForeighTrans demonstrate these selected firms' business complexity. Loss, SalesGrowth and SalesSTD represent these firms' financial and operational risk. The corporate governance is quite good with the higher mean of AuditReport and $L n B o D$. The information of the variable State shows that the percentage of state own enterpris es is quite higher in the sample firms. 
Table 1. Descriptive analys is

\begin{tabular}{lccccc} 
Variable & Obs & Mean & Std. reDev. & Min & Max \\
\hline ICQ & 2172 & 672.2 & 142.2 & 0 & 981.8 \\
ICQ_high & 2172 & 0.221 & 0.415 & 0 & 1 \\
ICQ_low & 2172 & 0.303 & 0.460 & 0 & 1 \\
NGO & 2172 & 3.096 & 0.151 & 2.690 & 3.330 \\
Trust & 2172 & 5.927 & 6.968 & 0.100 & 22.70 \\
lnAssets & 2172 & 21.84 & 1.145 & 18.16 & 26.06 \\
lnAge & 2172 & 2.260 & 0.641 & 0 & 3.091 \\
InShare & 2172 & 20.60 & 0.860 & 18.79 & 24.14 \\
BusiComplexity & 2172 & 0.256 & 0.177 & 0 & 0.971 \\
Merge & 2172 & 0.750 & 0.433 & 0 & 1 \\
ForeignTrans & 2172 & 0.314 & 0.464 & 0 & 1 \\
Loss & 2172 & 0.0792 & 0.270 & 0 & 1 \\
SalesGrowth & 2172 & 0.282 & 2.867 & -0.980 & 110.1 \\
Big4 & 2172 & 0.0115 & 0.107 & 0 & 1 \\
AuditReport & 2172 & 0.971 & 0.167 & 0 & 1 \\
lnBoD & 2172 & 2.190 & 0.195 & 1.386 & 2.773 \\
State & 2172 & 0.583 & 0.493 & 0 & 1 \\
SalesSTD & 2172 & $1.420 \mathrm{e}+09$ & $3.550 \mathrm{e}+09$ & $2.244 \mathrm{e}+06$ & $3.710 \mathrm{e}+10$ \\
\hline
\end{tabular}

\subsubsection{Correlation Analysis}

In the table of correlation matrix, any variable is marked as 1-star symbol if it has statistically significant at $10 \%$. ICQ is correlated with Trust (0.0884). Trust has also correlated with LnAge (0.1291), BusiComplexity (-0.1878), ForeignTrans (0.0973), Loss (-0.0606) and Big4 (0.1308).

Table 2. Correlation Matrix

\begin{tabular}{|c|c|c|c|c|c|c|c|c|c|c|c|c|c|c|c|}
\hline & ICQ & Trust & LnAssets & LnAge & LnShare & BusiComplexit & Merge & ForeignTrans & Loss & SalesGrth & Big 4 & AuditRept & $\ln B o D$ & State & SalesSTD \\
\hline$I C Q$ & 1 & & & & & & & & & & & & & & \\
\hline Trust & $0.0884 *$ & 1 & & & & & & & & & & & & & \\
\hline LnAssets & $0.3660^{*}$ & 0.0293 & 1 & & & & & & & & & & & & \\
\hline LnAge & $-0.0579^{*}$ & $0.1291 *$ & $0.3085^{*}$ & 1 & & & & & & & & & & & \\
\hline LnShare & $0.2234^{*}$ & 0.055 & $0.8328^{*}$ & $0.3027 *$ & 1 & & & & & & & & & & \\
\hline BusiComplexity & $-0.1107^{*}$ & $-0.1878^{*}$ & -0.0217 & 0.0164 & 0.0298 & 1 & & & & & & & & & \\
\hline Merge & 0.0517 & 0.0366 & $0.0733^{*}$ & 0.0232 & 0.0478 & $-0.1101 *$ & 1 & & & & & & & & \\
\hline ForeignTrans & $0.1128 *$ & $0.0973 *$ & $0.1142 *$ & $-0.0720^{*}$ & $0.0803^{*}$ & $-0.1176 *$ & 0.0211 & 1 & & & & & & & \\
\hline Loss & $-0.4768^{*}$ & $-0.0606^{*}$ & $-0.0935^{*}$ & $0.0799 *$ & -0.0319 & $0.1175^{*}$ & $-0.0634^{*}$ & -0.0551 & 1 & & & & & & \\
\hline SalesGrowth & 0.0012 & 0.0042 & -0.0239 & 0.0279 & 0.0165 & $0.0698^{*}$ & -0.0058 & -0.0065 & -0.0215 & 1 & & & & & \\
\hline Big4 & $0.0725^{*}$ & $0.1308^{*}$ & $0.0857^{*}$ & $0.0721 *$ & $0.0648^{*}$ & -0.0052 & 0.0024 & $0.0665 *$ & -0.0157 & -0.007 & 1 & & & & \\
\hline AuditReport & $0.3724 *$ & 0.0015 & $0.2064 *$ & $-0.0756^{*}$ & 0.0511 & -0.0131 & -0.0094 & $0.0564 *$ & $-0.2262^{*}$ & $-0.1150 *$ & $-0.0593^{*}$ & 1 & & & \\
\hline $\ln B o D$ & $0.0810^{*}$ & -0.0468 & $0.2497^{*}$ & $0.1200 *$ & $0.2359^{*}$ & $0.1151^{*}$ & 0.0079 & -0.028 & 0.0324 & 0.0008 & -0.001 & 0.0064 & 1 & & \\
\hline State & -0.0077 & 0.0508 & $0.2658^{*}$ & $0.4161^{*}$ & $0.2471^{*}$ & $0.1634 *$ & -0.0347 & $-0.0694 *$ & $0.0579^{*}$ & 0.0268 & $0.0563 *$ & 0.0064 & $0.1801^{*}$ & 1 & \\
\hline Sales STD & $0.2378 *$ & 0.0006 & $0.5027 *$ & $0.1206 *$ & $0.3970 *$ & -0.0439 & 0.0354 & $0.1473 *$ & $-0.0555^{*}$ & 0.0498 & 0.018 & 0.0522 & $0.0833^{*}$ & $0.1261^{*}$ & 1 \\
\hline
\end{tabular}

Standard errors in the correlation matrix: $* * * \mathrm{p}<0.01, * * \mathrm{p}<0.05, * \mathrm{p}<0.1$ 


\subsection{Multivariate Regression Analysis}

In Table 3, the OLS regression results demonstrate in the three columns: ICQ, ICQ_high and ICQ_low. The regression results in column 1 show a strong relationship between Trust and ICQ, reflecting that firms with higher trust level have higher internal control quality $(p<0.01)$. This result testifies that null hypothesis in model 1 does exist. The colu mn 2 measures the relationship between ICQ_high and Trust, while, the colu mn 3 measures between ICQ_low and Trust. The results in column 2 mean that in higher ICQ region, Trust is positively associated with ICQ_high. This relationship is statistically significant at the confidence level of $1 \%$. In the colu $\mathrm{mn} 3$, the relationship between Trust and ICQ_low is negatively related at the statistical confidence level of $1 \%$. The results of column 2 and 3 show that null hypothesis in model 3 and 4 does exist.

Table 3. Regression analys is

\begin{tabular}{|c|c|c|c|}
\hline VARIABLES & $\begin{array}{l}\text { (1) } \\
\text { ICQ }\end{array}$ & $\begin{array}{c}\text { (2) } \\
\text { ICQ_high }\end{array}$ & $\begin{array}{c}(3) \\
\text { ICQ_low }\end{array}$ \\
\hline Trust & $\begin{array}{c}1.243 * * * \\
(0.393)\end{array}$ & $\begin{array}{c}0.00443 * * * \\
(0.00165)\end{array}$ & $\begin{array}{c}-0.00550 * * * \\
(0.00146)\end{array}$ \\
\hline $\ln$ Assets & $\begin{array}{c}50.42 * * * \\
(4.659)\end{array}$ & $\begin{array}{c}0.122 * * * \\
(0.0177)\end{array}$ & $\begin{array}{c}-0.117 * * * \\
(0.0173)\end{array}$ \\
\hline $\ln \mathrm{Age}$ & $\begin{array}{c}-14.73 * * * \\
(4.812)\end{array}$ & $\begin{array}{l}-0.00708 \\
(0.0192)\end{array}$ & $\begin{array}{c}0.0244 \\
(0.0178)\end{array}$ \\
\hline lnShare & $\begin{array}{c}-20.38 * * * \\
(5.543)\end{array}$ & $\begin{array}{l}0.0382^{*} \\
(0.0208)\end{array}$ & $\begin{array}{c}0.0603 * * * \\
(0.0205)\end{array}$ \\
\hline BusiComplexity & $\begin{array}{l}-24.71 \\
(15.28)\end{array}$ & $\begin{array}{l}-0.0325 \\
(0.0580)\end{array}$ & $\begin{array}{l}-0.00903 \\
(0.0566)\end{array}$ \\
\hline Merge & $\begin{array}{l}-1.494 \\
(5.391)\end{array}$ & $\begin{array}{l}-0.0214 \\
(0.0159)\end{array}$ & $\begin{array}{c}0.0174 \\
(0.0198)\end{array}$ \\
\hline ForeignTrans & $\begin{array}{c}6.265 \\
(5.577)\end{array}$ & $\begin{array}{c}0.0281 \\
(0.0199)\end{array}$ & $\begin{array}{l}-0.0340^{*} \\
(0.0206)\end{array}$ \\
\hline $\operatorname{loss}$ & $\begin{array}{c}-181.4 * * * \\
(8.890)\end{array}$ & $\begin{array}{c}-0.102 * * * \\
(0.0261)\end{array}$ & $\begin{array}{c}0.626 * * * \\
(0.0327)\end{array}$ \\
\hline Sales Growth & $\begin{array}{l}1.199 \\
(0.812)\end{array}$ & $\begin{array}{l}-0.00104 \\
(0.00239)\end{array}$ & $\begin{array}{l}5.13 \mathrm{e}-05 \\
(0.00299)\end{array}$ \\
\hline $\operatorname{Big} 4$ & $\begin{array}{c}67.73 * * * \\
(24.55)\end{array}$ & $\begin{array}{l}0.199 * * \\
(0.0954)\end{array}$ & $\begin{array}{l}-0.0386 \\
(0.0910)\end{array}$ \\
\hline AuditReport & $\begin{array}{c}169.9 * * * \\
(15.89)\end{array}$ & $\begin{array}{l}-0.00320 \\
(0.0521)\end{array}$ & $\begin{array}{c}-0.225 * * * \\
(0.0587)\end{array}$ \\
\hline $\ln B o D$ & $\begin{array}{c}28.57 * * \\
(13.84)\end{array}$ & $\begin{array}{c}0.0193 \\
(0.0532)\end{array}$ & $\begin{array}{l}-0.0922^{*} \\
(0.0513)\end{array}$ \\
\hline State & $\begin{array}{c}-15.62 * * * \\
(6.047)\end{array}$ & $\begin{array}{c}-0.0743 * * * \\
(0.0241)\end{array}$ & $\begin{array}{c}0.0529 * * \\
(0.0224)\end{array}$ \\
\hline SalesSTD & $\begin{array}{c}2.34 \mathrm{e}-09 * * * \\
(8.66 \mathrm{e}-10)\end{array}$ & $\begin{array}{l}0 * * * \\
(0)\end{array}$ & $\begin{array}{l}-0 \\
(0)\end{array}$ \\
\hline 2010.Year & $\begin{array}{c}-15.94 * * \\
(6.260)\end{array}$ & $\begin{array}{l}-0.0335^{*} \\
(0.0173)\end{array}$ & $\begin{array}{c}0.0285 \\
(0.0230)\end{array}$ \\
\hline 2011.Year & $\begin{array}{c}-57.95 * * * \\
(6.410)\end{array}$ & $\begin{array}{c}-0.110 * * * \\
(0.0182)\end{array}$ & $\begin{array}{l}0.0459^{*} \\
(0.0235)\end{array}$ \\
\hline 2012.Year & $\begin{array}{c}-39.63 * * * \\
(6.566)\end{array}$ & $\begin{array}{c}-0.112 * * * \\
(0.0190)\end{array}$ & $\begin{array}{c}0.0509 * * \\
(0.0241)\end{array}$ \\
\hline Constant & $\begin{array}{c}-157.9^{* *} \\
(71.61)\end{array}$ & $\begin{array}{c}-3.182 * * * \\
(0.282)\end{array}$ & $\begin{array}{c}1.910^{* * * *} \\
(0.265)\end{array}$ \\
\hline $\begin{array}{l}\text { Observations } \\
\text { Number of ID }\end{array}$ & $\begin{array}{c}2,172 \\
543\end{array}$ & $\begin{array}{c}2,172 \\
543 \\
\end{array}$ & $\begin{array}{c}2,172 \\
543\end{array}$ \\
\hline
\end{tabular}

Standard errors in parentheses

$* * * \mathrm{p}<0.01, * * \mathrm{p}<0.05, * \mathrm{p}<0.1$ 
In Table 4, NGO substitutes for Trust. In column 1, the analysis shows that the relationship between $N G O$ and ICQ is strongly associated at the statistical confidence level of $1 \%$. In column 2 , the result reflects that $N G O$ has not strong relationship with ICQ_high. However, in column 3, the analysis shows that there is statistically significant inverse association between $N G O$ and ICQ_low. All these results testify that null hypothesis in model 2 and model 4 does exist. When $N G O$ substitutes Trust, there is no significantly association between $N G O$ and ICQ_high which is the null hypothesis in model 3.

Table 4. Regression analysis

\begin{tabular}{|c|c|c|c|}
\hline VARIABLES & $\begin{array}{c}(1) \\
\text { ICQ }\end{array}$ & $\begin{array}{c}(2) \\
\text { ICQ_high }\end{array}$ & $\begin{array}{c}(3) \\
\text { ICQ_low }\end{array}$ \\
\hline NGO & $\begin{array}{c}45.76^{* * *} \\
(18.05)\end{array}$ & $\begin{array}{c}0.100 \\
(0.0760)\end{array}$ & $\begin{array}{c}-0.193 * * * \\
(0.0671)\end{array}$ \\
\hline $\ln$ Assets & $\begin{array}{c}49.54 * * * \\
(4.658)\end{array}$ & $\begin{array}{c}0.120 * * * \\
(0.0178)\end{array}$ & $\begin{array}{c}-0.113 * * * \\
(0.0173)\end{array}$ \\
\hline $\ln$ Age & $\begin{array}{c}-12.71 * * * \\
(4.790)\end{array}$ & $\begin{array}{c}-0.000684 \\
(0.0191)\end{array}$ & $\begin{array}{c}0.0155 \\
(0.0178)\end{array}$ \\
\hline lnShare & $\begin{array}{c}-19.76^{* * *} \\
(5.545)\end{array}$ & $\begin{array}{l}0.0403 * \\
(0.0209)\end{array}$ & $\begin{array}{c}0.0575 * * * \\
(0.0206)\end{array}$ \\
\hline BusiComplexity & $\begin{array}{c}-26.60 * \\
(15.30)\end{array}$ & $\begin{array}{l}-0.0457 \\
(0.0581)\end{array}$ & $\begin{array}{r}0.000621 \\
(0.0568)\end{array}$ \\
\hline Merge & $\begin{array}{l}-1.370 \\
(5.395)\end{array}$ & $\begin{array}{l}-0.0212 \\
(0.0159)\end{array}$ & $\begin{array}{c}0.0168 \\
(0.0199)\end{array}$ \\
\hline ForeignTrans & $\begin{array}{c}6.076 \\
(5.605)\end{array}$ & $\begin{array}{c}0.0293 \\
(0.0200)\end{array}$ & $\begin{array}{l}-0.0335 \\
(0.0208)\end{array}$ \\
\hline $\operatorname{los} s$ & $\begin{array}{c}-181.6^{* * * *} \\
(8.894)\end{array}$ & $\begin{array}{c}-0.104 * * * \\
(0.0262)\end{array}$ & $\begin{array}{c}0.627 * * * \\
(0.0327)\end{array}$ \\
\hline Sales Growth & $\begin{array}{c}1.213 \\
(0.812)\end{array}$ & $\begin{array}{c}-0.000994 \\
(0.00239)\end{array}$ & $\begin{array}{l}-9.78 \mathrm{e}-07 \\
(0.00299)\end{array}$ \\
\hline Big 4 & $\begin{array}{c}71.98 * * * \\
(24.50)\end{array}$ & $\begin{array}{l}0.217 * * \\
(0.0954)\end{array}$ & $\begin{array}{l}-0.0585 \\
(0.0910)\end{array}$ \\
\hline AuditReport & $\begin{array}{c}170.8 * * * \\
(15.91)\end{array}$ & $\begin{array}{l}-0.00105 \\
(0.0522)\end{array}$ & $\begin{array}{c}-0.229 * * * \\
(0.0588)\end{array}$ \\
\hline $\ln \mathrm{BoD}$ & $\begin{array}{c}28.53 * * \\
(13.87)\end{array}$ & $\begin{array}{c}0.0169 \\
(0.0534)\end{array}$ & $\begin{array}{l}-0.0918 * \\
(0.0515)\end{array}$ \\
\hline State & $\begin{array}{c}-14.92 * * \\
(6.055)\end{array}$ & $\begin{array}{c}-0.0721 * * * \\
(0.0242)\end{array}$ & $\begin{array}{c}0.0499 * * \\
(0.0225)\end{array}$ \\
\hline Sales STD & $\begin{array}{c}2.39 \mathrm{e}-09 * * * \\
(8.69 \mathrm{e}-10)\end{array}$ & $\begin{array}{c}0 * * * \\
(0)\end{array}$ & $\begin{array}{l}-0 \\
(0)\end{array}$ \\
\hline 2010. Year & $\begin{array}{c}-16.20 * * * \\
(6.261)\end{array}$ & $\begin{array}{c}-0.0344 * * \\
(0.0173)\end{array}$ & $\begin{array}{c}0.0297 \\
(0.0230)\end{array}$ \\
\hline 2011.Year & $\begin{array}{c}-58.36 * * * \\
(6.411)\end{array}$ & $\begin{array}{c}-0.111 * * * \\
(0.0182)\end{array}$ & $\begin{array}{c}0.0477 * * \\
(0.0235)\end{array}$ \\
\hline 2012. Year & $\begin{array}{c}-40.20 * * * \\
(6.566)\end{array}$ & $\begin{array}{c}-0.114 * * * \\
(0.0190)\end{array}$ & $\begin{array}{c}0.0534 * * \\
(0.0241)\end{array}$ \\
\hline Constant & $\begin{array}{c}-290.9 * * * \\
(89.71)\end{array}$ & $\begin{array}{c}-3.468 * * * \\
(0.363)\end{array}$ & $\begin{array}{c}2.471 * * * \\
(0.333)\end{array}$ \\
\hline $\begin{array}{l}\text { Observations } \\
\text { Number of ID }\end{array}$ & $\begin{array}{c}2,172 \\
543\end{array}$ & $\begin{array}{c}2,172 \\
543\end{array}$ & $\begin{array}{c}2,172 \\
543\end{array}$ \\
\hline
\end{tabular}

Standard errors in parentheses

$* * * \mathrm{p}<0.01, * * \mathrm{p}<0.05, * \mathrm{p}<0.1$ 


\section{Robust Tests}

It is possible that other managerial features influence on internal control quality and trust as well. Top executives' ability can influence the reputation and then influence the trust level. Higher managerial ability can also improve the safeguard of the internal control system. Is the original assumption that trust is related with the internal control quality simple due to the managerial ability that also matters for the internal control quality? This paper tries to find the factor that site out the managerial ability from the trust level. To apply the method advocated by Damerjian et al. (2013), the ABILITY for each firm is solved for measuring managerial ability; The managerial compensation COMP can also reflect the managerial ability. This paper regresses Trust on these 2 proxies for managerial ability of each listed firm. The residual after the regression (Trust-Residual) can be considered the trust factor that is not due to managerial ability. Then the research regresses the Trust_Residual within the orig inal assumption model. The regression results are demonstrated in Table 5. It is found that the relationship between Trust_Residual and ICQ is statistically significant positive association in column 1. Column 2 shows that Trust_Residual is strongly associated with ICQ_high that means in upper level ICQ firms, more trust will increase more internal control quality; Colu mn 3 reflects that Trust_Residual is negatively related with ICQ_low that testifies in lower level ICQ firms, abnormal trustworthiness will decrease the internal control quality. This results show that abnormal trustworthiness play positively effects on internal control quality when ICQ is extre me high. While, when ICQ is extreme low, abnormal trustworthiness would cause less effective communication, less control on the compliance of financial reporting and play negatively effects on internal control quality. All the regression results in the robust tests clearly shows that the null hypotheses do exist.

Table 5. Robust tests

\begin{tabular}{|c|c|c|c|}
\hline VARIABLES & $\begin{array}{l}\text { (1) } \\
\text { ICQ }\end{array}$ & $\begin{array}{c}(2) \\
\text { ICQ_high }\end{array}$ & $\begin{array}{c}\text { (3) } \\
\text { ICQ_low }\end{array}$ \\
\hline Trust_Residual & $\begin{array}{c}1.000 * * * \\
(0.194)\end{array}$ & $\begin{array}{c}0.00419 * * * \\
(0.000749)\end{array}$ & $\begin{array}{c}-0.00370 * * * \\
(0.000721)\end{array}$ \\
\hline $\ln$ Assets & $\begin{array}{c}-0.00246 \\
(10.67)\end{array}$ & $\begin{array}{c}-0.0885^{* *} \\
(0.0411)\end{array}$ & $\begin{array}{l}0.0700^{*} \\
(0.0396)\end{array}$ \\
\hline $\ln \mathrm{Age}$ & $\begin{array}{c}-0.00306 \\
(5.381)\end{array}$ & $\begin{array}{c}0.0534 * * \\
(0.0212)\end{array}$ & $\begin{array}{l}-0.0314 \\
(0.0200)\end{array}$ \\
\hline lnShare & $\begin{array}{c}0.00229 \\
(6.647)\end{array}$ & $\begin{array}{c}0.123 * * * \\
(0.0252)\end{array}$ & $\begin{array}{l}-0.0160 \\
(0.0246)\end{array}$ \\
\hline BusiComplexity & $\begin{array}{c}-0.00596 \\
(16.31)\end{array}$ & $\begin{array}{c}0.0722 \\
(0.0613)\end{array}$ & $\begin{array}{l}-0.0942 \\
(0.0604)\end{array}$ \\
\hline Merge & $\begin{array}{c}-0.00478 \\
(5.376)\end{array}$ & $\begin{array}{l}-0.0135 \\
(0.0159)\end{array}$ & $\begin{array}{c}0.0117 \\
(0.0198)\end{array}$ \\
\hline ForeignTrans & $\begin{array}{c}0.000474 \\
(5.732)\end{array}$ & $\begin{array}{l}0.00465 \\
(0.0203)\end{array}$ & $\begin{array}{l}-0.0119 \\
(0.0212)\end{array}$ \\
\hline $\operatorname{loss}$ & $\begin{array}{l}-0.0530 \\
(36.63)\end{array}$ & $\begin{array}{c}0.652 * * * \\
(0.138)\end{array}$ & $\begin{array}{l}-0.0442 \\
(0.136)\end{array}$ \\
\hline Sales Growth & $\begin{array}{c}0.000731 \\
(0.843)\end{array}$ & $\begin{array}{c}-0.00599 * * \\
(0.00254)\end{array}$ & $\begin{array}{c}0.00446 \\
(0.00311)\end{array}$ \\
\hline Big 4 & $\begin{array}{l}0.0183 \\
(28.50)\end{array}$ & $\begin{array}{l}-0.0872 \\
(0.109)\end{array}$ & $\begin{array}{l}0.206^{*} \\
(0.106)\end{array}$ \\
\hline AuditReport & $\begin{array}{l}0.0542 \\
(36.86)\end{array}$ & $\begin{array}{c}-0.719 * * * \\
(0.138)\end{array}$ & $\begin{array}{c}0.404 * * * \\
(0.137)\end{array}$ \\
\hline $\ln B o D$ & $\begin{array}{c}0.00378 \\
(14.71)\end{array}$ & $\begin{array}{l}-0.0990 * \\
(0.0563)\end{array}$ & $\begin{array}{c}0.0149 \\
(0.0545)\end{array}$ \\
\hline State & $\begin{array}{c}0.000637 \\
(6.674)\end{array}$ & $\begin{array}{l}-0.00822 \\
(0.0263)\end{array}$ & $\begin{array}{l}-0.00546 \\
(0.0247)\end{array}$ \\
\hline Sales STD & $\begin{array}{c}0 \\
(9.68 \mathrm{e}-10)\end{array}$ & $\begin{array}{l}0^{* *} \\
(0)\end{array}$ & $\begin{array}{l}0^{* *} \\
(0)\end{array}$ \\
\hline 2010.Year & -0.00202 & 0.0334 & -0.0302 \\
\hline
\end{tabular}




\begin{tabular}{lccc} 
& $(6.992)$ & $(0.0211)$ & $(0.0257)$ \\
2011.Year & -0.00365 & $0.134^{* * *}$ & $-0.168^{* * *}$ \\
& $(13.04)$ & $(0.0473)$ & $(0.0482)$ \\
2012.Year & -0.00101 & 0.0548 & $-0.0953^{* *}$ \\
& $(10.20)$ & $(0.0356)$ & $(0.0377)$ \\
Constant & 0.0196 & $-2.520^{* * *}$ & $1.324^{* * *}$ \\
& $(77.28)$ & $(0.302)$ & $(0.286)$ \\
& & & \\
Observations & 2,172 & 2,172 & 2,172 \\
Number of ID & 543 & 543 & 543 \\
\hline
\end{tabular}

Standard errors in parentheses

$* * * \mathrm{p}<0.01, * * \mathrm{p}<0.05, * \mathrm{p}<0.1$

\section{Summary}

\subsection{Conclusions}

To build up an effective internal control framework is the requirements for modern corporation administration. Higher internal control quality can reduce the cost of finance, detect and prevent fraud and errors, safeguard assets, encourage employees to follow policy, comply with legal regulation and other benefits for the firms. This paper investigates the relationship between trust and internal control quality based on Chinese capital market' evidences. In this paper, social trust is measured to represent trust. The financial accounting data sourc es come from CSMAR and DIB databases. The trust index is based on the research by Zhang (2002). With the OLS regression analysis, this research finds that there is statistical significant between trust and internal control quality at the confidence level of $1 \%$. That means higher trust level leads to higher internal control quality. The development of NGOs can reflect the trust level in the region (Zhang, 2002). Furthermore, this paper makes regression analysis between $N G O$ and ICQ. The result still testifies the null hypothesis that trust has strong association with internal control quality. Under some extreme situation that $I C Q$ quality is extreme high or low, it is found that trust is positively related to ICQ_high when $I C Q$ is more than third quartile in the ICQ inde $\mathrm{x}$, while, trust is reversely associated with ICQ_low when ICQ is less than one quartile in the ICQ index. There is a robust test in this paper. Because managerial ability factors might also contribute to trust and internal control quality as well, to site out managerial ability from trust is a necessary step for avoiding endogeneity issues. The new variable Trust_Residual is made after the regression analysis and considered as the trust factor that are not due to managerial ability. Finally, it is found that Trust_Residual is also strongly associated with ICQ $(p<0.1)$. In sum, trust is the driver of internal control quality in Chinese stock markets.

\subsection{Limitations and Further Research Suggestions}

In this paper, social trust represents the trust level for the firms. This might a weakness for statistical analysis. It would be better if there is some trust data for each specific listed firm in China's stock markets. Although this paper tries to solve endogeneity issue within the robust test section, there might be more detail analysis in future research. In China, some factors, such as, culture, political factor and economic factors, might be further considered in potential research in this area.

\section{References}

Altamuro, J., \& Beatty, A. (2010). How does internal control regulation affect financial reporting? Journal of Accounting and Economics, 49, 58-74.

Ashbaugh-Skaife, H., Collins, D., \& Kinney, W. (2007). The discovery and reporting of internal control deficiencies prior to SOX-mandated audits. Journal of Accounting and Economics, 44(1-2), 166-192.

Barney, J.B., \& Hansen, M.H. (1994). Trustworthiness as a source of competitive advantage. Strategic Management Journal, 15. 175-190.

Boss, R.W. (1978). Trust and managerial problem solving revisited. Group \& Organization Management, 3(3), 331-342.

Brockner, J., Siegel, P., Daly J., Tyler T., \& Martin, C. (1997). When trust matters: the moderating effect of outcome favorability. Administrative science quarterly, 42(3), 558-5.

Chu, X.P., \& Li, H.Z. (2003). Trust and the development of family firms. Management World, 6. (in Chinese) 
COSO, The 2013 COSO Framework \& SOX Compliance. Retrieved form https://www.coso.org/Pages/guidance.aspx

Das, T. K., \& Teng, B.S. Between trust and control: developing confidence in partner cooperation in alliances. Academy of Management Review, 23, 491-512.

Demerjian, P., Lev, B., Lewis, M.F., \& Mcvay, S.E. (2013). Managerial ab ility and earnings quality. The Accounting Review, 88, 463-98.

Dirks, K.T., \& Ferrin, D.L. (2002). Trust in leadership: meta-analytic findings and implications for research and practice. Journal of applied psychology, 87(4), 611-628.

Dore, R. (1983). Goodwill and the spirit of capitalism. British Journal of Sociology, 34, 459-482.

Doyle, J., Ge, W., \& Mc Vay, S. (2007). Determinants of weaknesses in internal control over financial reporting. Journal of Accounting and Economics, 44(1), 193-223. https://doi.org/10.1016/j.jacceco.2006.10.003

Fend, M., Li, C., \& McVay, S. (2009). Internal control and management guidance. Journal of Accounting and Economics, 48, 190-209.

Fudenberg, D., \& Tirole, J. (1992). Game Throry. MIT Press, Cambridge.

Fukuyama, F. (1995). Trust: The social virtues and the creation of prosperity. The Free Press.

Garrett, J., Hoitash, R., \& Prawiff, D. F. (2014). Trust and financial reporting quality. Journal of Accounting Research, 52(5), https://doi.org/10.1111/1475-679X.12063

Goh, B.W., \& Li, D. (2011). Internal controls and conditional conservatism. Accounting Review, 86(3), 975-1005. https://doi.org/10.2308/accr.00000041

Gu lati, R. (1995). Does familiarity breed trust? The Implications of repeated ties for contractual choice in alliances. Academy of Management Journal, (38), 85-112.

Hoitash, U., Hoitash, R., \& Bedard, J.C. (2009). Corporate governance and internal control over financial reporting: a comparison of regulatory regimes. Accounting Review, 84(3), 839-867. https://doi.org/10.2308/accr.2009.84.3.839

Kim, J.G., Song, B.Y., \& Zhang, L.D. (2011). Internal control weakness and bank loan contracting: evidence from SOX section 404 disclosures. Accounting review, 86(4), 1157-1188.

Kim, W.C., \& Maruborgne, R.A. (1993). Procedural justice, attitudes, and subsidiary top management compliance with multinationals' corporate strategic decisions. Academy of management Journal,(36), 502-526.

Kreps, D. (1986). Corporate culture and economic theory. In M. Tsuchiya (Ed.), Technological Innovation and Business strategy. Nihon Keizai Shimbum, Inc.

Luhmann, N. (1979). Trust and Power. Chichester, England: Wiley.

Naiker, V., \& Sharma, D.S. (2009). Former audit partners on the audit committee and internal control deficiencies. Accounting review, 84(2), 559-587. https://doi.org/10.2308/accr.2009.84.2.559

Ouchi, W.G. (1979). A conceptual framework for the design of organizational control mechanisms. Managemnt Science, 25, 833-48.

Pan, Y., Wu, C. P., \& Shi, X.K. (2010). Social capital, Law protection and IPO earnings management. Accounting Research, 5. (in Chinese)

Porter, T., \& Lilly, B. (1996). The effects of conflict, trust, and task commitment on project team performance. International Journal of Conflict Management, 7, 361-376.

Rich, G. (1997). The sales manager as a role model: effects on trust, job satisfaction and performance of salespeople. Journal of the Academy of Marketing Science, 25 (4), 319-328.

Ring, P.S., \& Van De Ven. (1994). Developmental Processes of Cooperative Interorganizational Relationships. Academy of Management Review, 19(1), 90-118.

Robinson, S. (1996). Trust and the breach of the psychological contract. Administrative Science Quarterly, 41(4), 574-599.

Rousseau, D.M., Sitkin, S.B., Burt, R.S., \& Camerer, C. (1998). Not so different after all: A cross-discipline view of trust. Academy of Management Review, 23, 393-404. 
Sabel, C.F. (1993). Studied trust: Build ing new forms of cooperation in a volatile economy. Human Relations, 46(9), 1133-1170.

Skaife, H.A., Weenman, D., \& Wangerin, D. (2013). Internal control over financial reporting and managerial rent extraction: evidence from the profitability of insider trading. Journal of Accounting and Economics, 55, 91-110.

Wang, X., Yu, J., \& Fan, G. (2013). Business Environment Index for China's Provinces. China CITIC Press.

$\mathrm{Xu}, \mathrm{H} .$, \& Lin, Z.G. Trust levels, organizational structure and systemdesign for the enterprise internal control.

Yan, C. L. (2012). Social capital, innovation and long-term economic growth. Economic Research Journal, 11. (in Chinese)

Zhang, D.L., \& Li, S.H. (2012). Social trust, political relationship and the private enterprises' bank loans. Accounting Research, 8. (in Chinese)

Zhang, W.Y. (2002). Reputational foundation of the legal system. Economic Journal Research, 1. (in Chinese)

Zhang, W.Y., \& Ke, R.Z. (2002). Trust in China: a cross -regional analysis. Economic Research Journal, 10.

Zucher, L.G. (1986). Production of trust: Institutional sources of economic structure. In B.M. Staw \& L.L. Cummins (Eds.), Research in organizational behavior (Vol. 8, pp. 53-112). Greenwich, CT: JAI Press.

\section{Notes}

Note 1. The scope of social capital is much more broad. Social capital includes social trust, NGO, donation, etc.

Note 2. COSO. The Committee of Sponsoring Organizations of the Treadway Commission (COSO) is a joint initiative of the five private sector organizations and is dedicated to providing thought leadership through the development of frameworks and guidance on enterprise risk management, internal control and fraud deterrence.

Note 3. The financial institutes, such as commercial banks, insurance firms and security firms, have quite different financial reporting standards with other non-financial firms; B Share firms in China are only for overseas investors; ST firms have higher probability to be retired from the stock market simply due to the worse financial situations.

\section{Appendix}

Table 6. Variable definitions

\begin{tabular}{lll}
\hline Variable & Description & Definition \\
\hline $\begin{array}{l}\text { Dependent Variable } \\
\text { ICQ }\end{array}$ & Internal Control Quality & $\begin{array}{l}\text { Internal control index (source DIB } \\
\text { database) }\end{array}$ \\
ICQ_high & Higher Internal Control Quality & $\begin{array}{l}\text { ICQ more than 75\% percentile (source } \\
\text { DIB database) } \\
\text { ICQ_low }\end{array}$ \\
Lower Internal Control Quality & $\begin{array}{l}\text { ICQ less than 25\% percentile (source DIB } \\
\text { database) }\end{array}$
\end{tabular}

$\underline{\text { Testable Variable }}$

Trust

$N G O$

Social Trust

NGO Development Index

\section{Control Variable}

-Firm Features

LnAssets
Firm Size
Social Trust level for each province in China (source Zhang and Ke, 2002)

NGO index for each province in China (source Wang, et al., 2013)

The natural log of the firm's total assets in year $t$ (source CSMAR) 
LnAge $\quad$ Firm Age

LnShare

-Firm Complexity

BusiComplexity

Merge

-Financial Risks

ForeignTrans

Loss

SalesGrowth

SalesSTD

-Firm Governance

Big4

AuditReport

LnBoD

State
Business Complexity

Merger \& Acquisition

Foreign Exchange Transaction

Net Loss

Sales Growth Ratio

Sales Volatility

Auditing by Big 4 firms

Audit Report Quality

Size of Board of Directors

SOES
The natural log of the number of years that the firm is listed in the capital markets (source CSMAR)

The natural log of the sum of share capital and capital reserve (premium) in year $t$ (source CSMAR)

The proportion of non-current assets divided by total assets (source CSMAR)

Dummy variable. 1 if the number of merger and acquisition is more than zero in year $\mathrm{t}$, and 0 otherwise (source CSMAR)

Dummy variable. 1 if there is foreign currency transaction in year $\mathrm{t}$, and 0 otherwise (source CSMAR)

Dummy variable. 1 if the net income is less than zero in year $t$, and 0 otherwise

(source CSMAR)

Sales revenue in year $t$ divided by sales revenue in year $\mathrm{t}-1$, then minus 1 (source CSMAR)

Standard deviation of sales divided by average assets over the last 5 years (2008-2012) (source CSMAR)

Dummy variable. 1 if the firm is audited by big 4 accounting firms, and 0 otherwise (source CSMAR)

Dummy variable. 1 if the audit report is standard clean report, and 0 otherwise (source CSMAR)

The natural $\log$ of the No. of directors (source CSMAR)

Dummy variable. 1 for SOE, and 0 for others (source CSMAR) 